\title{
EL MERCADO DE HUEVO PARA PLATO EN MÉXICO, 1960-2012
}

\author{
THE TABLE EGG MARKET IN MÉXICO, 1960-2012
}

\author{
Susana Cruz-Jiménez*, Roberto García-Mata, José S. Mora-Flores, Roberto C. García-Sánchez \\ Colegio de Postgraduados. Campus Montecillo. Carretera México-Texcoco km 36.5. \\ Montecillo, Texcoco, Edo. De México. 56230. (cruz.susana@colpos.mx) (rory@colpos.mx) \\ (saturmf@colpos.mx) (rcgarcia@colpos.mx).
}

\begin{abstract}
RESUMEN
El huevo es importante en la alimentación humana por su alto índice proteínico y amplia disponibilidad en el mercado; es de fácil preparación y con precio competitivo contra otras fuentes de proteína de origen animal. En 2012 México registró un consumo de 20.8 kilogramos, el mayor per cápita de huevo en el mundo. El objetivo de este estudio fue analizar el mercado del huevo para plato en México y sus factores determinantes. Se utilizó un modelo econométrico de ecuaciones simultáneas con información del periodo 1970-2012. La oferta resultó inelástica a los precios al productor de huevo, pollo y alimento balanceado; la demanda es inelástica a los precios al consumidor de huevo, chile, carne de porcino, frijol, y al ingreso. El incremento del precio nominal al consumidor de huevo de $73 \%$, que se registró entre julio y agosto de 2012, por efecto de la caída en la producción originada por el brote de gripe aviar, debió aumentar solo 45.78 \%; la diferencia se debió a cuestiones especulativas.
\end{abstract}

Palabras clave: modelo econométrico, elasticidad, oferta, demanda.

\section{INTRODUCCIÓN}

$\mathrm{E}$ 1 consumo de huevo se ha extendido y está en aumento a nivel mundial, debido a su alto contenido proteínico, así como a su amplia disponibilidad en el mercado, fácil preparación y precio competitivo en relación con otros productos ricos en proteínas de origen animal. De 1970 a 2012 el consumo mundial per cápita promedio pasó de 11.51 a 16.27 kilogramos y registró una tasa de crecimiento media anual (TCMA) de $0.83 \%$. En ese periodo el consumo per cápita en México aumentó de 7.11 a 20.8

* Autor responsable * Author for correspondence.

Recibido: abril, 2014. Aprobado: febrero, 2016.

Publicado como ARTÍCULO en ASyD 13: 385-399. 2016.
Abstract

Egg is important in the human diet because it has a high protein index and is widely available in the market; it is easy to prepare and has a competitive price against other sources of protein of animal origin. In 2012, México recorded 20.8 kilograms, the highest per capita consumption of egg in the world. The objective of this study was to analyze the table egg market in México and its defining factors. An econometric model of simultaneous equations was used with information for the 1970-2012 period. The offer tuned out to be inelastic at producer prices of egg, chicken and balanced meal; the demand is inelastic at consumer prices of egg, chili, pork meat, bean, and income. The increase of $73 \%$ in nominal consumer price of egg, which was found between July and August 2012, due to the fall in production caused by the avian flu outbreak, should have increased only $45.78 \%$; the difference was due to speculative issues.

Key words: econometric model, elasticity, offer, demand.

\section{INTRODUCTION}

$\mathrm{E}$ gg consumption has been expanding and is increasing at the global level, due to its high protein content, and because of its broad availability in the market, easy preparation and competitive price with regards to other products that are rich in proteins of animal origin. From 1970 to 2012 the global average per capita consumption grew from 11.51 to 16.27 kilograms and showed an average annual growth rate (AAGR) of $0.83 \%$. In this period the per capita consumption in México increased from 7.11 to $20.8 \mathrm{~kg}$; in China, from 1.89 to $20.4 \mathrm{~kg}$; in Singapore, from 8.19 to $18.8 \mathrm{~kg}$; in Colombia, from 4.79 to $14.6 \mathrm{~kg}$; and in Argentina, from 7.58 to $12.6 \mathrm{~kg}$. In the meantime, in the United States, it decreased from 19.72 to $15.5 \mathrm{~kg}$; in Nueva Zealand, from 18.46 to $13.8 \mathrm{~kg}$; and in Japan, from 
kg; en China, de 1.89 a 20.4 kg; en Singapur, de 8.19 a $18.8 \mathrm{~kg}$; en Colombia, de 4.79 a 14.6 kg; y en Argentina, de 7.58 a $12.6 \mathrm{~kg}$. En tanto, en Estados Unidos de América disminuyó de 19.72 a 15.5 kg; en Nueva Zelanda, de 18.46 a 13.8 kg; y en Japón, de 16.92 a $16.3 \mathrm{~kg}$ (FAO, 2013; UNA, 2013). El crecimiento del consumo per cápita de huevo en México puede explicarse por su precio competitivo con respecto a otras fuentes de proteína; de esta manera, con un salario mínimo se adquieren en promedio 2.45 kilogramos de huevo, así como 1.84, 0.69 y 0.70 kilogramos de carne de pollo, porcino y bovino (UNA, 2013).

El incremento del consumo de huevo en el mundo y en México se debe a los gustos y preferencias de la población por este alimento, así como al aporte energético y proteínico del mismo. Adicionalmente, en un estudio de 14 años en el que se incluyó a 120 mil personas, $\mathrm{Hu}$, et al. (1999) encontraron que no existe mayor riesgo cardiovascular entre los individuos que consumen más de un huevo al día, situación que es contraria entre los que padecen diabetes. Por otro lado, al analizar a 30 mil personas durante seis años, Scrafford et al. (2011) encontraron que en personas adultas que consumen más de un huevo diario se reduce el riesgo de diabetes.

Por otra parte, Jillion et al. (2005) han señalado que un desayuno con huevo produce mayor saciedad y reduce significativamente el consumo de energía de otras fuentes que pudieran inducir mayor obesidad, por lo que es posible que ingerirlo no contribuya a generar sobrepeso.

Tomek y Kaiser (2014) señalan que la función de demanda para un alimento la determinan las variaciones del precio al consumidor del producto, el ingreso disponible y su distribución, los precios de productos sustitutos y complementarios, y los gustos y preferencias del consumidor. Con series históricas de 1960 a 1987 y de 1960 a 2003, y con estimaciones de mínimos cuadrados en dos etapas, López (1990) y Rojas (2005) obtuvieron coeficientes de elasticidad para el huevo. Para productos relacionados con éste, el primer autor usó jamón y leche; el segundo solo leche; y en la presente investigación se utilizó carne de porcino, así como queso, chile y frijol. Según Stamer, 1969, esto modifica el orden de magnitud de los coeficientes de elasticidad de la demanda estimados en las tres investigaciones.

Según datos de López (1990) y SIACON (2013), la producción nacional de huevo presentó un crecimiento
16.92 to $16.3 \mathrm{~kg}$ (FAO, 2013; UNA, 2013). The growth in per capita egg consumption in México can be explained by its competitive price compared to other sources of protein; thus, with one minimum wage an average of 2.45 kilograms of eggs can be acquired, as well as 1.84, 0.69 and 0.70 kilograms of chicken, pork and beef meat (UNA, 2013).

The increase in egg consumption in the world and in México is due to the tastes and preferences of the population for this food, and to its energetic and protein contribution. In addition, in a study of 14 years in which 120 thousand people were included, $\mathrm{Hu}$ et al. (1999) found that there is not a higher cardiovascular risk among individuals who consume more than one egg per day, situation that is different among those who suffer from diabetes. On the other hand, when analyzing 30 thousand people during six years, Scrafford et al. (2011) found that among adult people who consume more than one egg daily, the risk of diabetes was reduced.

On the other hand, Jillion et al. (2005) have mentioned that a breakfast with egg produces greater satiation and reduces significantly the energy consumption from other sources that may induce greater obesity, so it is possible that ingesting it does not contribute to generating overweight.

Tomek and Kaiser (2014) point out that the demand function for a food is determined by the variations in the consumer price of the product, the income available and its distribution, the prices of substitute and complementary products, and the tastes and preferences of the consumer. With historical series from 1960 to 1987 and from 1960 to 2003, and with minimum squares estimations in two stages, López (1990) and Rojas (2005) obtained elasticity coefficients for egg. For products related with it, the first author used ham and milk; the second, only milk; and in this study pork meat was used, as well as cheese, chili and bean. According to Stamer (1969), this modifies the order of magnitude of the coefficients of the demand elasticity estimated in the three studies.

According to data by López (1990) and SIACON (2013), national egg production presented an accelerated growth, going from 365745 tons in 1970 to 2386576 tons in 2012, showing an AAGR $4.57 \%$ higher than that of the population $(1.98 \%)$. With a production of 108.5 million boxes of eggs obtained in 2012 (UNA, 2013), México was the sixth global 
acelerado, pasando de 365745 toneladas en 1970 a 2 386576 toneladas en 2012, registrando una TCMA de $4.57 \%$ superior a la de la población (1.98\%). Con la producción de 108.5 millones de cajas de huevo obtenidas en 2012 (UNA, 2013), México se ubicó como el sexto productor mundial, después de China, EE. UU., la Unión Europea, la India y Japón, que en el mismo orden produjeron 1090, 218.4, 181.4, 178.3 y 114.3 millones de cajas. La producción nacional per cápita de huevo en México en 1970 y 2012 fue de 7.58 y 21.69 kilogramos, cantidades que abastecen el consumo nacional en $99.9 \%$, lo que hace al país autosuficiente en este alimento. Los principales estados productores en México son Jalisco (55\%), Puebla (15\%), Sonora (8 \%), región de la Comarca Lagunera (Durango y Coahuila) (5\%), Yucatán (4\%), Sinaloa (3\%), Nuevo León (2\%) y Guanajuato (2\%) (UNA, 2013), donde se localizan once de las principales empresas productoras encabezadas por Proteína Animal, Bachoco, El Calvario, Empresas Guadalupe, Socorro Romero Sánchez, Granjas Avícolas Rancho Grande, José Asunción, Productora de Huevos Gigantes, Gena Agropecuaria, Avícola González y González e Impulsora Agropecuaria Santa Rosa, que originan un mercado oligopólico que les permite imponer el precio de venta a su primer comprador. Las grandes empresas productoras de huevo aumentaron su participación en la producción, de 29 \% en 2006 y $45 \%$ en 2012; las medianas la disminuyeron de $50 \%$ a $36 \%$ y las pequeñas de $21 \%$ a $19 \%$ (UNA, 2013). Las empresas grandes se están integrando verticalmente, debido a que mantienen eslabonadas la producción y la comercialización del huevo; ello significa que los precios se entrelazan a través de la propiedad directa o por contrato del producto. La concentración oligopólica de la producción de las grandes empresas y su integración vertical les permite reducir costos de producción unitarios y de comercialización en lo referente al empaque del huevo, transporte y en la distribución del producto al mayoreo, en la que un alto porcentaje es ejecutado por los grandes productores, usando las bodegas de que disponen en la centrales de abasto del país. Esto disminuye los márgenes de comercialización y los precios que pagan los consumidores, sin menoscabo de los márgenes de ganancia de los productores y comercializadores.

López (1990) incluyó como variables explicativas de la oferta, al precio del alimento balanceado, mismo que hizo depender del precio del sorgo y de producer, after China, USA, the European Union, India and Japan, which in the same order produced 1090, 218.4, 181.4, 178.3 and 114.3 million boxes. The national per capita egg production in México in 1970 and 2012 was 7.58 and 21.69 kilograms, amounts that supply the national consumption in $99.9 \%$, making the country self-sufficient in this food. The main producing states in México are Jalisco (55\%), Puebla (15\%), Sonora (8\%), the Comarca Lagunera region (Durango and Coahuila) $(5 \%)$, Yucatán (4\%), Sinaloa (3\%), Nuevo León (2\%) and Guanajuato (2\%) (UNA, 2013), where eleven of the principal producing companies are located, led by Proteína Animal, Bachoco, El Calvario, Empresas Guadalupe, Socorro Romero Sánchez, Granjas Avícolas Rancho Grande, José Asunción, Productora de Huevos Gigantes, Gena Agropecuaria, Avícola González y González and Impulsora Agropecuaria Santa Rosa, which create an oligopoly market that allows them to impose the sales price to its first buyer. The large egg producing companies increased their participation in production, from $29 \%$ in 2006 to $45 \%$ in 2012; the medium ones decreased from $50 \%$ to $36 \%$, and the small ones from $21 \%$ to $19 \%$ (UNA, 2013). The large companies are becoming integrated vertically, because they maintain egg production and commercialization linked; this means that the prices are intertwined through direct property or through product contract. Oligopoly concentration of production into large companies and their vertical integration allows them to reduce unitary production and commercialization costs in what refers to egg packaging, transport, and distribution of the product wholesale, where a high percentage is executed by large producers, using the warehouses that they have in the country's wholesale supply centers. This decreases the trade margins and the prices that consumers pay, without harming the profit margins of producers and traders.

López (1990) included as explicative variables of the offer the price of balanced meal, which he forced to depend on the price of sorghum and soy; the producer price of egg, which he related with the official price; and the technology, which he represented with a trend variable. Rojas (2005) incorporated directly as explicative variables of the offer the price of balanced meal, technology -which he approximates to the food conversion to kilogram of egg -, the producer price of egg, a variable of trend, 
la soya; al precio al productor de huevo, que lo relacionó con el precio oficial, y a la tecnología, que la representó con una variable de tendencia. Rojas (2005) incorporó directamente como variables explicativas de la oferta el precio del alimento balanceado, a la tecnología, que la aproxima con la conversión alimenticia a kilogramo de huevo, el precio al productor de huevo, una variable de tendencia y una de clasificación con la que separa los periodos de economía cerrada (1960-1985) y abierta (1986 -2010). Además del precio al productor de huevo, la presente investigación incluye el precio al productor de pollo como producto competitivo del huevo, al alimento balanceado, la tecnología, una variable de clasificación y una de tendencia.

Cabe destacar que el alimento balanceado constituyó 69 \% del costo total de producción de un kilogramo de huevo en 2012 (UNA, 2013). De 1970 a 2012, los requerimientos de alimento balanceado para obtener uno de huevo pasaron de 2.8 a 2 kilogramos, lo que indica que la tasa de conversión aumentó de 0.36 a 0.50 kilogramos de huevo por uno de alimento. El progreso tecnológico provocó la disminución del precio real del alimento balanceado a una TCMA de $2.08 \%$ por año y la producción creció a una TCMA del $4.57 \%$, a pesar de que los precios reales al productor de huevo descendieron cada ańo en $3.42 \%$.

La producción de huevo es una fuente importante de empleo. Entre 1994 y 2012 generó 775 mil y 194 mil empleos directos, y 115 mil y 972 mil empleos indirectos. Asimismo, es una actividad altamente demandante de insumos agrícolas (granos forrajeros y pastas oleaginosas). En cuanto al consumo de granos forrajeros, en 1994 y 2010 la avicultura productora de huevo consumió, 2,516,028 y 4,155,546 toneladas de sorgo y maíz.

De 1970 al 2012, los precios reales del sorgo por tonelada disminuyeron de \$3095.24 a \$1958.64 (36.72\%); los del alimento balanceado pasaron de $\$ 7142.86$ a $\$ 3540.78$ (50.42\%), y el precio real al productor de huevo cayó de $\$ 24615.38$ a $\$ 5730.64$ la tonelada $(76.72 \%)$. El precio real al productor de huevo en relación con el valor real del alimento balanceado que se requiere para producir un kilogramo de huevo pasó de 1.524 a 1.596 en los respectivos años. Esto indica que, relativamente, el precio del huevo aumentó más que el del alimento balanceado (UNA, 2013). and one of classification with which he separates the periods of closed (1960-1985) and open (19862010) economy. In addition to the producer price of egg, this study includes the producer price of chicken as product that competes with egg, and balanced meal, technology, a classification variable, and one trend variable.

It should be highlighted that balanced meal constituted $69 \%$ of the total production cost of one kilogram of egg in 2012 (UNA, 2013). From 1970 to 2012, the requirements of balanced meal to obtain one of egg went from 2.8 to 2 kilograms, indicating that the rate of conversion increased from 0.36 to 0.50 kilograms of egg per one of meal. The technological progress caused the decrease in the real price of balanced meal to an AAGR of $2.08 \%$ per year and the production grew at an AAGR of $4.57 \%$, despite the real producer prices of egg decreasing each year by $3.42 \%$.

Egg production is an important source of employment. Between 1994 and 2012, it generated 775 thousand and 194 thousand direct jobs, and 115 thousand and 972 thousand indirect jobs. Likewise, it is an activity that is highly demanding of agricultural inputs (fodder grains and oleaginous pastes). With regards to the consumption of fodder grains, in 1994 and 2010 egg-producing poultry farming consumed 2516028 and 4155546 tons of sorghum and maize.

From 1970 to 2012, the real sorghum prices per ton decreased from $\$ 3095.24$ to $\$ 1958.64$ (36.72\%); those of balanced meal went from $\$ 7142.86$ to $\$ 3540.78(50.42 \%)$, and the real producer price of egg fell from $\$ 24615.38$ to $\$ 5730.64$ per ton $(76.72 \%)$. The real producer price of egg compared to the real value of balanced meal, which is required to produce one kilogram of egg, went from 1.524 to 1.596 in the corresponding years. This indicates that, relatively, the price of egg increased more than that of the balanced meal (UNA, 2013).

The objective of this research is to explain the functioning of the egg market in México; that is, to estimate the functions of offer and demand, and to determine the variables that condition them. The hypothesis is that the demand of this product in México is determined by real consumer prices of egg, pork meat, cheese, chili, bean and real income per capita, while the offer was determined by the real producer prices of egg, chicken and balanced meal, 
El objetivo de esta investigación es explicar el funcionamiento del mercado de huevo en México, es decir, estimar las funciones de oferta y demanda, y determinar las variables que las condicionan. La hipótesis es que la demanda de este producto en México la determinan los precios reales al consumidor de huevo, el de la carne de cerdo, queso, chile, frijol, y el ingreso real per cápita, mientras que a la oferta la determinan los precios reales al productor de huevo, el del pollo y del alimento balanceado, así como la tecnología, además de que el efecto del precio de importación de huevo es reducido en el mercado nacional del producto, debido a que el país es autosuficiente en este alimento.

\section{Metodología}

Stamer (1969) indica que la cantidad ofrecida de un producto agrícola en el mercado depende en primer lugar de las expectativas de beneficio (B) de los agricultores; si éstos estiman altas ganancias para el próximo periodo económico, la producción y la cantidad ofrecida aumentarán, y viceversa. Como el beneficio $B=Q(P-C M T)$ depende de la cantidad de producto vendida $(Q)$, del precio del producto $(P)$ y de los costos medios totales de producción (CMT), entonces la oferta futura la determina el precio esperado del producto y la evolución de los costos. Stamer (1969) y Tomek y Kaiser (2014) señalan que la oferta de un producto agrícola la determinan, además de las variaciones del precio esperado por el productor del bien bajo estudio, los precios de los insumos o factores de la producción, el estado de la técnica que está dada por la forma de la función de producción, los precios de productos competitivos y acoplados, y las restricciones institucionales.

La población en México consume huevo combinado con chile verde, cebolla, jitomate, queso y frijol; también lo come con chorizo, jamón y tocino En la estimación estos productos tuvieron el signo esperado y coeficientes significativos, como complementarios, chile verde, queso y frijol, los tres últimos se capturaron con el precio al consumidor de la carne de cerdo que resultó complementario del huevo.

El costo de producción de huevo se aproximó al precio del alimento balanceado que, como tal, incluye los precios de los granos forrajeros, sorgo y maíz, pasta de soya, mano de obra y la tecnología empleada para su fabricación. La tecnología es el factor que as well as technology, in addition to the effect of the import price of egg which is reduced in the national market of the product, because the country is selfsustainable in this food.

\section{Methodology}

Stamer (1969) indicates that the amount of an agricultural product offered in the market depends first on the farmers' expectations of benefit (B); if these estimate high profits for the next economic period, the production and the amount offered will increase, and vice versa. Since the benefit $B=Q(P-$ $C M T$ ) depends on the amount of product sold $(Q)$, the product price $(P)$, and the total average production costs $(A P C)$, then the future offer is determined by the expected price of the product and the evolution of costs. Stamer (1969) and Tomek and Kaiser (2014) point out that the offer of an agricultural product is determined, in addition to variations in the price expected by the producer of the good under study, the prices of inputs or production factors, the state of the technique that is given by the shape of the production function, the prices of competitive and coupled products, and the institutional restrictions.

The population in México consumes egg combined with green chili, onion, tomato, cheese and beans; they also eat it with chorizo, ham and bacon. In the estimation, these products had the sign expected and significant coefficients, as complementary goods, green chili, cheese and beans, the three latter were captured with the consumer price of pork meat, which was complementary to egg.

The production cost of egg approached the price of balanced meal which, as such, includes the prices of fodder grains, sorghum and maize, soy paste, labor, and technology used for its manufacture. Technology is the factor that has driven most the growth of egg production in México, which through genetic engineering has originated a hen that produces a higher number of eggs with the same amount of food and other inputs and, therefore, with the same total cost; that is, productivity per bird has increased and the production costs have reduced.

An econometric model of simultaneous equations of the egg market in México was formulated and 
más ha impulsado el crecimiento de la producción de huevo en México, misma que mediante la ingeniería genética ha originado una gallina que produce mayor cantidad de huevo con la misma cantidad de alimento y otros insumos y, por tanto, con el mismo costo total; es decir, se ha aumentado la productividad por ave y reducido los costos de producción.

Se formuló y estimó un modelo econométrico de ecuaciones simultáneas del mercado del huevo en México, en el que se involucran a las principales variables económicas que determinan a las funciones de la oferta y de la demanda, considerando la transmisión del precio de importación en los de mayoreo, productor y consumidor y, en consecuencia, sobre el saldo de comercio. El modelo especificado representa el funcionamiento del mercado interno, tomando en cuenta la influencia del mercado externo durante el periodo de 1960 a 2012. La estimación de los coeficientes se realizó mediante el método de mínimos cuadrados en dos etapas, con el procedimiento SYSLIN del paquete computacional SAS (Statistical Analysis System, v.9.0.). La coherencia estadística del mismo se determinó por medio del coeficiente de determinación $\left(\mathrm{R}^{2}\right)$, que indica la bondad de ajuste de cada una de las ecuaciones estimadas; la significancia global de los coeficientes de cada ecuación se observó con la prueba de $\mathrm{F}$ y la de cada coeficiente con la $t$ de Student o la razón de $t$. El aspecto económico del modelo se validó de acuerdo con los signos esperados indicados por la teoría económica de los coeficientes de cada ecuación, y por la magnitud de las elasticidades (García et al., 2004; Pérez et al., 2010; García et al., 2013).

La información para el periodo de 1970 al 2012 se obtuvo de López (1990) y Rojas (2005), la Unión Nacional de Avicultores (UNA, 2011, 2012 y 2013). Otras estadísticas se obtuvieron de la Organización de las Naciones Unidas para la Agricultura y la Alimentación (FAO, 2013), Sistema Nacional de Información e Integración de Mercados (SNIIM, 2013), Instituto Nacional de Estadística y Geografía (INEGI, 2013), Banco de México (Banxico, 2013), Sistema de Información Agroalimentaria de Consulta (SIACON, 2013).

El modelo econométrico lo constituyeron cinco relaciones funcionales y una identidad, tal como se indica a continuación:

$\mathrm{QPH}_{\mathrm{t}}=\alpha_{11}+\alpha_{12} \mathrm{PRHP}_{\mathrm{t}}+\alpha_{13} \mathrm{PPCPR}_{\mathrm{t}}+\alpha_{14}$ PRALIBA $_{\mathrm{t}}$ $+\alpha_{15} \mathrm{TECN}_{\mathrm{t}}+\alpha_{16} \mathrm{TE}_{\mathrm{t}}+\alpha_{16} \mathrm{D}_{\mathrm{t}}+\alpha_{1 \mathrm{t}}$ estimated, in which the main economic variables that determine the offer and demand functions are involved, taking into consideration the transmission of the import price into those of wholesale, producer and consumer, and, as consequence, on the trade balance. The model specified represents the functioning of the internal market, taking into account the influence of the external market during the 1960 to 2012 period. Estimating the coefficients was done through the minimum square method in two stages, with the SYSLIN procedure of the SAS software package (Statistical Analysis System, v.9.0.). Its statistical coherence was determined through a coefficient of determination $\left(\mathrm{R}^{2}\right)$, which indicates the goodness of fit in each one of the equations estimated; the global significance of the coefficients of each equation was observed with the $F$ test and that of each coefficient with the $t$ Student or $t$ frequency. The economic aspect of the model was validated according to the signs expected indicated by the economic theory of the coefficients of each equation, and by the magnitude of the elasticities (García et al., 2004; Pérez et al., 2010; García et al., 2013).

Information for the period of 1970 to 2012 was obtained from López (1990) and Rojas (2005), the National Poultry Producers' Union (Unión Nacional de Avicultores, UNA, 2011, 2012 and 2013). Other statistics were obtained from the United Nations Food and Agriculture Organization (FAO, 2013), National Information and Market Integration System (Sistema Nacional de Información e Integración de Mercados, SNIIM, 2013), National Institute for Statistics and Geography (Instituto Nacional de Estadistica y Geografía, INEGI, 2013), México's Central Bank (Banco de México, Banxico, 2013), and the Agrifood Information System for Consult (Sistema de Información Agroalimentaria de Consulta, SIACON, 2013).

The econometric model was constituted by five functional relations and one identity, as indicated next:

$\mathrm{QPH}_{\mathrm{t}}=\alpha_{11}+\alpha_{12} \mathrm{PRHP}_{\mathrm{t}}+\alpha_{13} \mathrm{PPCPR}_{\mathrm{t}}+\alpha_{14} \mathrm{PRALIBA}_{\mathrm{t}}$ $+\alpha_{15} \mathrm{TECN}_{\mathrm{t}}+\alpha_{16} \mathrm{TE}_{\mathrm{t}}+\alpha_{16} \mathrm{D}_{\mathrm{t}}+\alpha_{1 \mathrm{t}}$

$\mathrm{PRHP}_{\mathrm{t}}=\alpha_{21}+\alpha_{22}$ PRHMAY $_{\mathrm{t}}+\alpha_{23}$ CTHRT $_{\mathrm{t}}+\alpha_{2 \mathrm{t}}$ PRHMAY $_{\mathrm{t}}=\alpha_{31}+\alpha_{32}$ PIMPHR $_{\mathrm{t}}+\alpha_{33}$ PRHMM $_{\mathrm{t}}+\alpha_{3 \mathrm{t}}$ 
$\mathrm{PRHP}_{\mathrm{t}}=\alpha_{21}+\alpha_{22} \mathrm{PRHMAY}_{\mathrm{t}}+\alpha_{23} \mathrm{CTHRT}_{\mathrm{t}}+\alpha_{2 \mathrm{t}}$ PRHMAY $_{\mathrm{t}}=\alpha_{31}+\alpha_{32}$ PIMPHR $_{\mathrm{t}}+\alpha_{33}$ PRHMM $_{\mathrm{t}}+\alpha_{3 \mathrm{t}}$

$\mathrm{PRHC}_{\mathrm{t}}=\alpha_{41}+\alpha_{42} \mathrm{PRHMAY}_{\mathrm{t}}+\alpha_{4 \mathrm{t}}$

$\mathrm{QDPER}_{\mathrm{t}}=\alpha_{51}+\alpha_{52} \mathrm{PRHC}_{\mathrm{t}}+\alpha_{53} \mathrm{YNDRPER}_{\mathrm{t}}+\alpha_{54} \mathrm{PC}$ $\mathrm{CCR}_{\mathrm{t}}+\alpha_{55} \mathrm{PCQR}_{\mathrm{t}}+\alpha_{56} \mathrm{PCHISR}_{\mathrm{t}}+\alpha_{57} \mathrm{PCFR}_{\mathrm{t}}+\alpha_{5 \mathrm{t}}$

$\mathrm{SCE}_{\mathrm{t}}=\mathrm{QDH}_{\mathrm{t}}-\mathrm{QPH}_{\mathrm{t}}$

Las variables endógenas del modelo son: cantidad producida del huevo $\left(\mathrm{QPH}_{\mathrm{r}}\right)(\mathrm{t})$, los precios reales del huevo al productor (PRHP) $(\$ / t)$, al mayoreo (PRHMAY) (\$/t), al consumidor (PRHC) $(\$ / \mathrm{kg})$, cantidad demandada per cápita de huevo (QDPER) $(\mathrm{kg})$; y saldo de comercio exterior (SCE) (t). Las variables predeterminadas del modelo son: precio real del huevo de importación (PIMPHR $)(\$ / \mathrm{kg})$ al medio mayoreo (PRHMM) $(\$ / \mathrm{kg})$, al productor de la carne de pollo (PPCPR) ( $\$ / \mathrm{t}$ ), del alimento balanceado (PRALIBA) $(\$ / t)$, al consumidor de la carne de cerdo (PCCCR) $(\$ / \mathrm{kg})$, de queso (PCQR) $(\$ /$ $\mathrm{kg})$, de chile (PCHISR) $(\$ / \mathrm{kg})$, de frijol (PCFR) $(\$ /$ $\mathrm{kg})$, costo real de transporte de huevo (CTHR) $(\$ / \mathrm{t})$, tecnología $\left(\mathrm{TECN}_{\mathrm{r}}\right)$ (conversión alimenticia: gramos de huevo por uno de alimento); e ingreso real per cápita (YNDRPER) (miles de \$/año). Los valores nominales fueron transformados a valores reales con los índices de precios apropiados.

\section{Resultados y Discusión}

Las cinco ecuaciones de regresión que componen el modelo estimado mostraron una bondad de ajuste aceptable en términos del coeficiente de determinación $\left(\mathrm{R}^{2}\right)$, el cual está por arriba de 0.92 para todas las relaciones. Los resultados estimados en su forma estructural y reducida se presentan en los Cuadros 1 y 2. La prueba global $\mathrm{F}$ resultó significativa al $1 \%$ para todas las relaciones funcionales. Según la significancia individual de cada parámetro de las cinco ecuaciones, todas las variables explicativas resultaron significativas ("razón de $t$ " mayor que uno).

Los signos de los coeficientes de las variables de las cinco ecuaciones que conforman el modelo estructural estimado concuerdan con la teoría económica. Las elasticidades fueron calculadas con las derivadas parciales de cada ecuación y los valores
$\mathrm{PRHC}_{\mathrm{t}}=\alpha_{41}+\alpha_{42}$ PRHMAY $_{\mathrm{t}}+\alpha_{4 \mathrm{t}}$

$\mathrm{QDPER}_{\mathrm{t}}=\alpha_{51}+\alpha_{52} \mathrm{PRHC}_{\mathrm{t}}+\alpha_{53} \mathrm{YNDRPER}_{\mathrm{t}}+\alpha_{54} \mathrm{PC}$ $\mathrm{CCR}_{\mathrm{t}}+\alpha_{55} \mathrm{PCQR}_{\mathrm{t}}+\alpha_{56} \mathrm{PCHISR}_{\mathrm{t}}+\alpha_{57} \mathrm{PCFR}_{\mathrm{t}}+\alpha_{5 \mathrm{t}}$

$\mathrm{SCE}_{\mathrm{t}}=\mathrm{QDH}_{\mathrm{t}}-\mathrm{QPH}_{\mathrm{t}}$

The endogenous variables of the model are: amount of egg produced $(\mathrm{QPH})(\mathrm{t})$, real producer prices of egg (PRHP) (\$/t), wholesale prices (PRHMAY) $(\$ / \mathrm{t})$, consumer prices $\left(\mathrm{PRHC}_{\mathrm{r}}\right)(\$ / \mathrm{kg})$, amount of egg demanded per capita (QDPER) (kg); and foreign trade balance $\left(\mathrm{SCE}_{\mathrm{r}}\right)(\mathrm{t})$. The predetermined variables of the model are: real import price of egg (PIMPHR) $(\$ / \mathrm{kg})$, for medium-wholesale (PRHMM) $(\$ / \mathrm{kg})$, for chicken meat producer (PPCPR) ( $\$ / t)$, of balanced meal (PRALIBA) ( $\$ / t)$, for consumer of pork meat (PCCCR) $(\$ / \mathrm{kg})$, of cheese (PCQR $)(\$ / \mathrm{kg})$, of chili (PCHISR $)(\$ / \mathrm{kg})$, of beans $\left(\mathrm{PCFR}_{\mathrm{t}}\right)(\$ / \mathrm{kg})$, real cost of egg transport $\left(\mathrm{CTHR}_{\mathrm{r}}\right)(\$ / \mathrm{t})$, technology $\left(\mathrm{TECN}_{\mathrm{r}}\right)$ (food conversion: grams of egg per one of meal); and real per capita income (YNDRPER) (thousands of \$/ año). The nominal values were transformed into real values with the appropriate price indexes.

\section{Results AND Discussion}

The five regression equations that make up the estimated model showed a goodness of fit acceptable in terms of the coefficient of determination $\left(\mathrm{R}^{2}\right)$, which is above 0.92 for all the relationships. The results estimated in their structural and reduced form are presented in Tables 1 and 2. The global $F$ test was significant at $1 \%$ for all the functional relations. According to the individual significance of each parameter from the five equations, all the explicative variables were significant (" $t$ value" higher than one).

The signs of the coefficients of the variables of the five equations that make up the structural model estimated agree with the economic theory. The elasticities were calculated with the partial derivatives of each equation and the average values of the variables for the 1960-2012 period, with the aim of quantifying the effects of the explicative variables on the endogenous ones. The analysis of elasticities implicitly includes the concept of ceteris paribus, that is, that the effect of one variable in particular is such, insofar as the other variables remain constant (Table 3 ). 
promedio de las variables para el periodo 1960 2012, con el fin de cuantificar los efectos de las variables explicativas sobre las endógenas. El análisis de las elasticidades lleva implícito el concepto de ceteris paribus, es decir, que el efecto de una variable en particular es tal, en tanto las otras variables se mantienen constantes (Cuadro 3).

\section{Elasticidad precio de la oferta y la demanda}

La oferta estimada indica una relación directa e inelástica de 0.52 de la cantidad ofrecida con respecto al precio real al productor de huevo, coeficiente que resulta inferior a los de 0.63 y 0.534 obtenidos por López (1990) y Rojas (2005), lo cual se explica porque el volumen y el valor de la producción son más pequeños en los periodos 1960-1987 que en 1960-2003 y 1960 2012 de esta investigación. De acuerdo con el resultado respecto al promedio 1960-2012 se tiene que ante una disminución del $10 \%$ en el precio al productor, éste reacciona inelásticamente con un decremento en

\section{Price elasticity of offer and demand}

The offer estimated indicates a direct and inelastic relation of 0.52 of the amount offered with regards to the real price to the egg producer, coefficient that is lower than those of 0.63 and 0.534 obtained by López (1990) and Rojas (2005), which is explained because the volume and the value of the production are smaller in the period of 1960-1987 than in 19602003 and 1960-2012 from this study. According to the results with regards to the 1960-2012 average, it is found that in face of a $10 \%$ decrease in the producer price, it reacts inelastically with a decrease in the amount offered of $5.2 \%$ (59 $755 \mathrm{t}$ ) compared to the 1960-2012 average (1 $149135 \mathrm{t}$ ), which causes a fall of $14.68 \%$ in the income. This indicates that the fall in the producer price during the period under study has had a small effect on the decrease of egg production, which is counteracted by the positive effect of the other explicative variables of the offer

Cuadro 1. México: coeficientes de la forma estructural estimados para el mercado del huevo, 1960-2012.

Table 1. México: coefficients of the structural form estimated for the egg market, 1960-2012.

\begin{tabular}{|c|c|c|c|c|c|c|c|c|c|}
\hline \multirow{3}{*}{$\begin{array}{l}\text { Variables } \\
\text { dependientes } \\
\text { OFERTA } \\
\text { QPH }\end{array}$} & \multirow[t]{2}{*}{ Intercepto } & \multicolumn{6}{|c|}{ Variables independientes o explicativas } & \multirow[t]{2}{*}{$\mathrm{R}^{2} \mathrm{t}$} & \multirow[t]{2}{*}{ Prob $>F$} \\
\hline & & & & & & & & & \\
\hline & & PRHP & PPCPR & PRALIBA & TECN & $\mathrm{D}$ & $\mathrm{TE}$ & & \\
\hline & -381100.00 & 37.91 & -30.55 & -83.62 & 2458453.00 & -335792.00 & 41840.36 & 0.98 & $<0.0001$ \\
\hline Error estándar & 485062.50 & 10.01 & 10.41 & 30.08 & 1175268.00 & 95134.79 & 7311.67 & & \\
\hline Valor t & -0.79 & 3.79 & -2.94 & -2.78 & 2.09 & -3.53 & 5.72 & & \\
\hline \multicolumn{10}{|l|}{ PRECIOS } \\
\hline \multirow[t]{2}{*}{ PRHP } & & PRHMAY & CTHR & & & & & & \\
\hline & 1572.44 & 0.58 & 2150.96 & & & & & 0.96 & $<0.0001$ \\
\hline Error estándar & 554.13 & 0.04 & 1053.00 & & & & & & \\
\hline Valor t & 2.84 & 15.88 & 2.04 & & & & & & \\
\hline \multirow[t]{2}{*}{ PRHMAY } & & PIMPHR & PRHMM & & & & & & \\
\hline & -543.25 & 0.06 & 0.92 & & & & & 0.99 & $<0.0001$ \\
\hline Error estándar & 387.73 & 0.02 & 0.02 & & & & & & \\
\hline Valor t & -1.40 & 2.97 & 55.04 & & & & & & \\
\hline \multirow[t]{2}{*}{ PRHC } & & PRHMAY & & & & & & & \\
\hline & 1223.23 & 1.28 & & & & & & 0.92 & $<0.0001$ \\
\hline Error estándar & 1286.55 & 0.05 & & & & & & & \\
\hline Valor t & 0.95 & 24.43 & & & & & & & \\
\hline \multicolumn{10}{|l|}{ DEMANDA } \\
\hline QDH & & PRHC & YNDRPER & PCCCR & PCQR & PCHISR & PCFR & & \\
\hline & 1954375.00 & -7.77 & 20.99 & -7.83 & -4.71 & -16.95 & -13.83 & 0.98 & $<0.0001$ \\
\hline Error estándar & 188305.90 & 2.94 & 2.01 & 2.07 & 2.14 & 7.09 & 7.38 & & \\
\hline Valor $\mathrm{t}$ & 10.38 & -2.65 & 10.43 & -3.78 & -2.20 & -2.39 & -1.88 & & \\
\hline
\end{tabular}

Fuente: elaboración propia con los resultados de la estimación del modelo econométrico. * Source: authors’ elaboration with results from estimation of the econometric model. 
Cuadro 2. México: coeficientes de la forma reducida estimados para el mercado del huevo, 1960-2012. Table 2. México: coefficients of the reduced form for the egg market, 1960-2012.

\begin{tabular}{|c|c|c|c|c|c|c|}
\hline \multirow{2}{*}{$\begin{array}{l}\text { Variables } \\
\text { predeterminadas }\end{array}$} & \multicolumn{6}{|c|}{ Variables endógenas } \\
\hline & $\mathrm{QPH}$ & PRHP & $\mathrm{QDH}$ & PRHMAY & PRHC & SC \\
\hline Intercepto & -333420.00 & 1257.87 & 1950291.00 & -543.25 & 525.35 & 2283711.00 \\
\hline PPCPR & -30.55 & 0.00 & 0.00 & 0.00 & 0.00 & 30.55 \\
\hline PRALIBA & -83.62 & 0.00 & 0.00 & 0.00 & 0.00 & 83.62 \\
\hline TECN & 2458453.00 & 0.00 & 0.00 & 0.00 & 0.00 & -2458453.00 \\
\hline $\mathrm{D}$ & -335792.00 & 0.00 & 0.00 & 0.00 & 0.00 & 335792.40 \\
\hline $\mathrm{TE}$ & 41840.36 & 0.00 & 0.00 & 0.00 & 0.00 & -41840.40 \\
\hline CTHR & 81532.32 & 2150.96 & 0.00 & 0.00 & 0.00 & -81532.30 \\
\hline PIMPHR & 1.43 & 0.04 & -0.65 & 0.06 & 0.08 & -2.08 \\
\hline PRHMM & 20.12 & 0.53 & -9.15 & 0.92 & 1.18 & -29.27 \\
\hline YNDRPER & 0.00 & 0.00 & 20.99 & 0.00 & 0.00 & 20.99 \\
\hline PCCCR & 0.00 & 0.00 & -7.83 & 0.00 & 0.00 & -7.83 \\
\hline PCQR & 0.00 & 0.00 & -4.71 & 0.00 & 0.00 & -4.71 \\
\hline PCHISR & 0.00 & 0.00 & -16.95 & 0.00 & 0.00 & -16.95 \\
\hline PCFR & 0.00 & 0.00 & -13.83 & 0.00 & 0.00 & -13.83 \\
\hline
\end{tabular}

Fuente: elaboración propia con los resultados de la estimación del modelo econométrico. * Source: authors' elaboration with results from estimation of the econometric model.

la cantidad ofrecida de $5.2 \%(59755 \mathrm{t})$ respecto al promedio 1960-2012 (1 149135 t), lo que provoca una caída de $14.68 \%$ en su ingreso. Lo anterior indica que la caída en el precio al productor en el periodo bajo estudio ha tenido un efecto pequeño en el descenso de la producción de huevo, mismo que es contrarrestado por el efecto positivo de las otras that stimulate the production of this food in México to a greater degree.

The amount demanded was inelastic, with a coefficient of -0.19 with regards to the consumer price of egg. This coefficient is lower in absolute value than -1.342 and -0.514 obtained by López (1990) and Rojas (2005), using historical series from 1960

Cuadro 3. México: elasticidades de oferta, demanda, transmisiones de precios y SCE, 1960-2012.

Table 3. México: offer, demand, transmission elasticities of prices and SCE, 1960-2012.

\begin{tabular}{|c|c|c|c|c|c|c|}
\hline \multirow{2}{*}{ Variables explicativas } & \multicolumn{6}{|c|}{ Variables endógenas } \\
\hline & $\mathrm{QPH}$ & PRHP & $\mathrm{QDH}$ & PRHMAY & PRHC & SC \\
\hline$\overline{\mathrm{PRHP}}$ & 0.52 & 0.00 & 0.00 & 0.00 & 0.00 & 0.00 \\
\hline PPCPR & -0.54 & 0.00 & 0.00 & 0.00 & 0.00 & 292.78 \\
\hline PRALIBA & -0.34 & 0.00 & 0.00 & 0.00 & 0.00 & 187.30 \\
\hline TECN & 0.86 & 0.00 & 0.00 & 0.00 & 0.00 & -467.94 \\
\hline $\mathrm{D}$ & -0.15 & 0.00 & 0.00 & 0.00 & 0.00 & 81.19 \\
\hline TE & 0.98 & 0.00 & 0.00 & 0.00 & 0.00 & -536.15 \\
\hline CTHR & 0.07 & 0.13 & 0.00 & 0.00 & 0.00 & -35.49 \\
\hline PIMPHR & 0.02 & 0.04 & -0.01 & 0.05 & 0.05 & -17.23 \\
\hline PRHMM & 0.39 & 0.75 & 0.18 & 0.97 & 0.93 & -310.59 \\
\hline PRHC & 0.00 & 0.00 & -0.19 & 0.96 & 0.00 & 0.00 \\
\hline YNDRPER & 0.00 & 0.00 & 0.98 & 0.00 & 0.00 & 529.71 \\
\hline PCCCR & 0.00 & 0.00 & -0.57 & 0.00 & 0.00 & -311.19 \\
\hline PCQR & 0.00 & 0.00 & -0.43 & 0.00 & 0.00 & -232.49 \\
\hline PCHISR & 0.00 & 0.00 & -0.30 & 0.00 & 0.00 & -164.13 \\
\hline PCFR & 0.00 & 0.00 & -0.19 & 0.00 & 0.00 & -103.43 \\
\hline
\end{tabular}

Fuente: elaboración propia con base a los coeficientes estimados y los promedios del periodo. Source: authors' elaboration based on the coefficients estimated and the period's average. 
variables explicativas de la oferta que incentivan en mayor medida la producción de este alimento en México.

La cantidad demandada resultó inelástica, con un coeficiente de -0.19 respecto al precio al consumidor de huevo. Este coeficiente es menor en valor absoluto al de -1.342 y -0.514 obtenidos por López (1990) y Rojas (2005), usando series históricas de 1960 a 1987 y de 1960 a 2003. La diferencia en el orden de magnitud de estos coeficientes de elasticidad teóricamente se explica porque con un grado de saturación creciente de la satisfacción de las necesidades, la elasticidad precio de la demanda disminuye y viceversa. El consumo per cápita promedio en kilogramos de los periodos antes referidos fue de 9.9 y 11.8 y de 13.54 para el periodo comprendido en esta investigación. Estos datos indican que el nivel de saturación en el consumo de huevo fue mayor en el último periodo que en los dos anteriores; por ello, la elasticidad precio de la demanda es mayor en el primer periodo que en los dos siguientes. Con base en la elasticidad antes reportada y ante una disminución de $10 \%$ del precio al consumidor, la cantidad demandada aumenta en $1.9 \%$ (21 $681 \mathrm{t}$ ) respecto al promedio 1960-2012 (1 $141096 \mathrm{t}$ ), lo cual disminuye en $8.3 \%$ el gasto del consumidor.

Con el coeficiente de elasticidad precio de la demanda de -0.19 estimado se puede evaluar el efecto en los precios al consumidor provocado por la caída de 17263 toneladas en la producción (8.7 \%), que ocurrió en agosto de 2012 cuando se registró una producción de 181016 toneladas de huevo comparado con las 198279 toneladas que se produjeron en julio del mismo año. Se calcula que la disminución ocurrió por la muerte de 21.9 millones de gallinas ponedoras debido al brote de gripe aviar registrado en los municipios de Tepatitlán, Acatic y San Juan de los Lagos, en los Altos de Jalisco, México, en agosto de 2012 (SIAP, 2012). Al respecto, el 1 de noviembre de 2012 la SAGARPA manifestó que gracias al cerco sanitario y a la aplicación oportuna de 50 millones de vacunas por medio del Servicio Nacional de Sanidad, Inocuidad y Calidad Agroalimentaria (SENASICA) cuatro semanas despues de su aparición, se pudo erradicar el virus A1H7N3 causante de dicha enfermedad.

El precio nominal al consumidor de huevo sin gripe aviar a finales de julio de 2012 era de $\$ 19.37 \mathrm{~kg}$, y por la presencia de esta enfermedad, subió a $\$ 33.51$ $\mathrm{kg}$ en agosto, lo que implica un incremento de $73 \%$ to 1987 and from 1960 to 2003 . The difference in the order of magnitude of these elasticity coefficients is explained theoretically because with a growing saturation degree of the satisfaction of needs, the price elasticity of the demand decreases, and vice versa. The average per capita consumption in kilograms in the periods mentioned before was 9.9 and 11.8 , and 13.54 in the period covered by this study. These data indicate that the level of saturation in the consumption of egg was higher in the last period than in the two prior; therefore, the price elasticity of the demand is higher in the first period than in the two next ones. Based on the elasticity reported before and facing a decrease of $10 \%$ in the consumer price, the amount demanded increased in $1.9 \%(21681 \mathrm{t})$ with regards to the 1960-2012 average (1 $141096 \mathrm{t}$ ), which decreases the consumer's expenditure in $8.3 \%$.

With the estimated price elasticity coefficient of the demand of -0.19 , the effect on consumer prices provoked by the fall of 17263 tons in production $(8.7 \%)$ can be evaluated, which took place in August 2012 when a production of 181 016 tons of egg was found, compared to the 198 279 tons that were produced in July of the same year. It was calculated that the decrease occurred because of the death of 21.9 million laying hens due to the outbreak of avian flu registered in the municipalities of Tepatitlán, Acatic and San Juan de los Lagos, in the Jalisco Highlands, México, during August 2012 (SIAP, 2012). In this regard, on November $1^{\text {st }} 2012$ the SAGARPA manifested that thanks to the sanitary barrier and the timely application of 50 million vaccines through the National Agrifood Sanitation, Innocuousness and Quality Service (Servicio Nacional de Sanidad, Inocuidad y Calidad Agroalimentaria, SENASICA) four weeks after its appearance, the A1N7N3 virus, cause of the disease, could be eradicated.

The nominal consumer price of egg without avian flu at the end of July 2012 was $\$ 19.37 \mathrm{~kg}$, and because of the presence of this disease, it rose to $\$ 33.51 \mathrm{~kg}$ in August, which implies an increase of $73 \%$ (Table 4 ). Based on the estimated price elasticity coefficient of the demand $\left(E_{i j}\right)$ of $(-0.19)$, which is defined as the percentage change in the amount demanded $(\Delta \% \mathrm{Q})$, due to a percentage change in the price $(\Delta \% \mathrm{P})$, ceteris paribus, the increase that the consumer prices should have 
(Cuadro 4). Con base en el coeficiente de elasticidad precio propia de la demanda $\left(\mathrm{E}_{\mathrm{ii}}\right)$ estimada de $(-0.19)$, que se define como el cambio porcentual en la cantidad demandada $(\Delta \% \mathrm{Q})$ debido a un cambio porcentual en el precio $(\Delta \% \mathrm{P})$, ceteris paribus, se estimó el incremento que por reacción de la demanda debieron experimentar en agosto de 2012 los precios al consumidor:

$$
\begin{array}{r}
E_{i i}=\frac{\Delta \% Q}{\Delta \% P} ;-0.19=\frac{-0.087}{\Delta \% P} \therefore \\
\Delta \% P=\frac{-0.087}{-0.19}=45.78 \%
\end{array}
$$

El aumento porcentual del precio al consumidor ocasionado por el desabasto interno que provocó el brote de gripe aviar se estimó en 45.78 \%; esto indica que el precio nominal al consumidor debió aumen$\operatorname{tar}$ de $\$ 19.37 / \mathrm{kg}$ a $\$ 28.24 / \mathrm{kg}$, en lugar de $\$ 33.51 /$ $\mathrm{kg}$, que se registró en agosto de 2012 (Cuadro 4). La diferencia de $27.22 \%$ del incremento de $73 \%$ en que subieron los precios se considera que fue ocasionado por la especulación de los comerciantes en las distintas plazas de venta, es decir, el sobre precio de $\$ 5.27 / \mathrm{kg}$ adicional a $\$ 28.24 / \mathrm{kg}$ se estima fue en gran medida un incremento especulativo.

Ahora, considerando los precios mensuales al productor $(\$ 13.81 / \mathrm{kg})$ y al consumidor $(19.37 / \mathrm{kg})$ que se registraron en julio de 2012 se obtiene un margen absoluto y relativo de comercialización de $\$ 5.56 / \mathrm{kg}(28.7 \%)$. Suponiendo que este margen absoluto se mantenga en agosto del mismo ańo, el precio al consumidor en este mes sería igual al precio al productor de agosto de $2012(\$ 20.16 / \mathrm{kg})$, experienced in August 2012 as a reaction to the demand, was estimated:

$$
\begin{array}{r}
E_{i i}=\frac{\Delta \% Q}{\Delta \% P} ;-0.19=\frac{-0.087}{\Delta \% P} \therefore \\
\Delta \% P=\frac{-0.087}{-0.19}=45.78 \%
\end{array}
$$

The percentage increase in the consumer price caused by the internal lack of supply that the avian flu outbreak caused was estimated at $45.78 \%$; this indicates that the nominal consumer price should have increased from $\$ 19.37 / \mathrm{kg}$ to $\$ 28.24 / \mathrm{kg}$, instead of $\$ 33.51 / \mathrm{kg}$, which was seen in August 2012 (Table 4). The difference of $27.22 \%$ from the increase of $73 \%$ that prices rose is considered to have been caused by the speculation of traders in different sales spots, that is, the overprice of $\$ 5.27 / \mathrm{kg}$ additional to $\$ 28.24 / \mathrm{kg}$ was estimated to be largely a speculative increase.

Now, considering the monthly producer $(\$ 13.81 /$ $\mathrm{kg})$ and consumer $(19.37 / \mathrm{kg})$ prices that were seen in July 2012, an absolute and relative trade margin of $\$ 5.56 / \mathrm{kg}(28.7 \%)$ is obtained. Assuming that this absolute margin is sustained in August of the same year, the consumer price during that month would be equal to the producer price in August $2012(\$ 20.16 / \mathrm{kg})$, plus the absolute trade margin $(\$ 5.56 / \mathrm{kg})$; that is, $\$ 25.72 / \mathrm{kg}$, which is lower than the one estimated, using elasticities $(\$ 28.24 / \mathrm{kg})$, if the absolute trade margin that was found in August $2012(\$ 7.787 / \mathrm{kg})$ is considered, which results in a consumer price of $\$ 27.95$ pesos $/ \mathrm{kg}$. This also

Cuadro 4. Cambios en los precios semanales de huevo blanco al menudeo en distintas plazas de mercado, julio-septiembre de 2012. Table 4. Changes in the weekly wholesale prices of white egg in different market spots, July-September 2012.

\begin{tabular}{lccccc}
\hline \multirow{2}{*}{ Central de abasto } & \multicolumn{2}{c}{ Precio $\$ / \mathrm{kg}$} & $\Delta^{\dagger}$ \\
\cline { 2 - 5 } & $1-30$ Septiembre* & $\Delta \%^{\dagger}$ & $23-27$ Julio* $^{*}$ & $20-24$ Agosto* & Julio-Agosto \\
\hline Iztapalapa, D.F. & 30.25 & -13.57 & 19.00 & 35.00 & 84.21 \\
Ecatepec & 29.25 & -18.75 & 18.50 & 36.00 & 94.59 \\
Acapulco & 32.00 & 15.52 & 20.50 & 27.70 & 35.12 \\
Morelia & 31.00 & -3.13 & 18.00 & 32.00 & 77.78 \\
Aguascalientes & 28.00 & 3.70 & 19.30 & 27.00 & 39.90 \\
La Laguna & 27.45 & -1.96 & 19.00 & 28.00 & 47.37 \\
Colima & 29.25 & -5.65 & 17.00 & 31.00 & 82.35 \\
Guadalajara & 28.75 & -24.34 & 19.50 & 38.00 & 94.87 \\
Mérida & 32.25 & 15.18 & 26.00 & 28.00 & 7.69 \\
Media & 29.87 & -10.86 & 19.37 & 33.51 & 73.00 \\
\hline
\end{tabular}

${ }^{\dagger}$ Cambio porcentual. *Ponderados por población. * Percentage change. *Weighted by population.

Fuente: elaborado con datos de (SNIIM, 2013). Source: elaborated with data from (SNIIM, 2013). 
más el margen absoluto de comercialización $(\$ 5.56 /$ $\mathrm{kg}$ ), o sea, de $\$ 25.72 / \mathrm{kg}$, que es inferior al estimado, usando elasticidades $(\$ 28.24 / \mathrm{kg})$, si se considera el margen absoluto de comercialización que se registró en agosto de $2012(\$ 7.787 / \mathrm{kg})$, el cual arroja un precio al consumidor de pesos $27.95 / \mathrm{kg}$. Esto también indica que el aumento en el precio al consumidor de agosto de 2012 fue resultado de la especulación que llevaron a cabo los comerciantes en las diferentes plazas de mercado del país como antes fue indicado.

\section{Elasticidades de la forma reducida}

El modelo en la oferta identifica a la producción de pollo como competitiva de la de huevo; de esta manera, una disminución de $10 \%$ en los precios al productor de pollo haría que su cantidad ofrecida baje y que la oferta de huevo se desplace a la derecha, ocasionando que la cantidad ofrecida de huevo respecto al promedio (1 $149135 \mathrm{t})$ aumente $5.4 \%$ (62 $053 \mathrm{t}$ ), lo cual origina que el ingreso de los productores de huevo se incremente $5.4 \%$.

El alimento balanceado para ponedoras es un factor importante de la producción ya que constituye alrededor de $69 \%$ del costo total de producción de un kilogramo de huevo. Para este factor se estimó un coeficiente de elasticidad de la oferta de -0.34 , que resulta inferior al de -0.507 obtenido por Rojas (2005). La diferencia se explica básicamente por el número de observaciones usadas en la estimación; en este caso, una disminución de $10 \%$ en el precio del alimento balanceado hará que la curva de oferta precio se desplace a la derecha y que la cantidad ofrecida aumente $3.4 \%$ (39 $071 \mathrm{t}$ ) y el ingreso del productor se incremente $3.4 \%$. La elasticidad de la oferta del huevo con respecto al precio del alimento balanceado indica la importancia de obtener precios competitivos de los granos y oleaginosas en el mercado nacional e internacional, los cuales determinan al precio del alimento balanceado. De esta manera, una baja de precios de estos insumos harán que el precio del alimento disminuya, lo cual estimulará la producción $y$, desde luego, a la cantidad ofrecida de huevo.

Asimismo, un aumento de $10 \%$ en la tecnología, que se considera como la conversión alimenticia, ocasionaría que la oferta de huevo se desplace a la derecha, haciendo que la cantidad ofrecida de huevo aumente $8.8 \%$ (101 124 t) y que el ingreso del productor se incremente en $8.8 \%$. indicates that the increase in the consumer price of August 2012 was a result of the speculation that the traders participated in, in the different market spots of the country, as was indicated before.

\section{Elasticities of the reduced form}

The model in the offer identified chicken production as competitive to that of egg; therefore, a decrease of $10 \%$ in the producer prices of chicken would make the amount offered decrease and the egg offer move to the right, causing for the amount of egg offered with regards to the average (1 $149135 \mathrm{t}$ ) to increase $5.4 \%(62053 \mathrm{t})$, which causes for the income of egg producers to increase $5.4 \%$.

The balanced meal for laying hens is an important factor of production, since it constitutes around $69 \%$ of the total production costs of a kilogram of eggs. For this factor, an elasticity coefficient of the offer of -0.34 was estimated, which is lower than the one obtained by Rojas (2005), of -0.507 . The difference is explained basically by the number of observations used in the estimation; in this case, a decrease of $10 \%$ in the price of balanced meal will make the curve of the offer price move to the right and the amount offered increase in 3.4\% (39071 t), and the producer income increase in $3.4 \%$. The offer elasticity of egg compared to the price of the balanced meal indicates the importance of obtaining competitive prices of grains and oleaginous plants in the national and international market, which determine the price of the balanced meal. Thus, a decrease in prices of these inputs will make the price of the meal decrease, which will stimulate the production and, naturally, the amount of egg offered.

Likewise, an increase of $10 \%$ in technology, which is considered as food conversion, would cause for the egg offer to move to the right, making the amount of egg offered increase $8.8 \%$ (101 $124 \mathrm{t}$ ) and the producer's income increase $8.8 \%$.

In the demand, the income, ceteris paribus, is one of the variables that stimulate most its growth. A coefficient of 0.98 was obtained, which is higher than the 0.53 obtained by Rojas (2005) and the 0.89 estimated by López (1990). An annual increase of $4 \%$ in the income moves the demand to the right and provokes an increase of $3.9 \%$ in the amount demanded (44 $502 \mathrm{t}$ ). The income elasticity of the demand of egg estimated for the average of the series 
En la demanda, el ingreso, ceteris paribus, es una de las variables que más impulsa su crecimiento. Se obtuvo un coeficiente de 0.98 , que es mayor al de 0.53 obtenido por Rojas (2005) y al de a 0.89 estimado por López (1990). Un aumento anual de 4 \% en el ingreso desplaza a la derecha a la demanda y provoca un incremento de $3.9 \%$ en la cantidad demandada (44 502 t). La elasticidad ingreso de la demanda estimada de huevo para el promedio de la serie usada clasifica a este alimento en México como un bien necesario, dado el bajo nivel de consumo de proteína animal que se registra en el país (UNA, 2012); por ello, es de esperar que la cantidad demandada continúe creciendo conforme el ingreso se incremente.

Los resultados indican que la carne de cerdo, el queso, el chile y el frijol son bienes complementarios del huevo. Ante una disminución de $10 \%$ en los precios al consumidor de estos alimentos, ceteris paribus, se espera que la demanda de huevo se desplace a la derecha, provocando que su cantidad demandada se incremente en $5.7 \%$ (65 $043 \mathrm{t}$ ), $4.3 \%$ (49 $068 \mathrm{t}$ ), $3 \%(34234 \mathrm{t})$ y $1.9 \%(21681 \mathrm{t})$.

\section{Elasticidad de la transmisión de precios}

Las transmisiones de precios en el mercado de huevo resultaron inelásticas. En este caso, un aumento de $10 \%$ en el precio al mayoreo hará que el precio al productor y al consumidor aumenten $7.7 \%$ y $9.6 \%$, respectivamente. Bajo este escenario la cantidad ofrecida se incrementa en $4 \%$ y la demandada disminuirá $1.8 \%$. Estos resultados indican que en el mercado al mayoreo hay una rápida transmisión de precios hacia los consumidores, debido a que en la distribución del huevo al mayoreo y menudeo operan mercados altamente competitivos y, también, de la compra al mayoreo hacia el productor donde opera la función de acopio o concentración que se inicia en la producción y termina con la compra del producto por los mayoristas, función que realizan los mismos avicultores.

Un incremento de $10 \%$ en el precio al medio mayoreo trae consigo un aumento del precio al mayoreo de $9.7 \%$. Este mismo aumento se transmite hacia los precios al productor y al consumidor, los cuales suben $7.5 \%$ y $9.7 \%$, respectivamente. A su vez, la oferta se incrementa $3.9 \%$ y la demanda disminuye $1.8 \%$. Se deriva que el precio al medio mayoreo tiene una incidencia inmediata sobre la cantidad demanda y ofrecida. used classifies this food in México as a necessary good, given the low consumption level of animal protein that is seen in the country (UNA, 2012); therefore, it should be expected that the amount demanded will continue to grow as the income increases.

The results indicate that pork meat, cheese, chili and beans are complementary goods to egg. With a decrease of $10 \%$ in the consumer prices of these foods, ceteris paribus, it is expected for the egg demand to move to the right, provoking for the amount demanded to increase in $5.7 \%(65043 \mathrm{t}), 4.3 \%$ $(49068 \mathrm{t}), 3 \%(34234 \mathrm{t})$ and $1.9 \%(21681 \mathrm{t})$.

\section{Elasticity of price transmission}

Transmissions of prices in the egg market were inelastic. In this case, an increase of $10 \%$ in the wholesale price would make the producer and consumer price increase $7.7 \%$ and $9.6 \%$, respectively. Under this scenario the amount offered will increase $4 \%$ and the demand will decrease $1.8 \%$. These results indicate that in the wholesale market there is a fast transmission of prices towards consumers, because in the egg distribution for wholesale and retail, highly competitive markets operate, and, also, because the wholesale purchase to the producer where the stockpile or concentration function operates, which begins in the production and ends with the purchase of the product by wholesalers, a function performed by the poultry producers themselves.

An increase of $10 \%$ in the price at mediumwholesale brings with it an increase in the wholesale price of $9.7 \%$. This same increase is transmitted towards the producer and consumer prices, which rise $7.5 \%$ and $9.7 \%$, respectively. In turn, the offer increases $3.9 \%$ and the demand decreases $1.8 \%$. From this derives that the medium-wholesale price has an immediate influence on the amount demanded and offered.

An increase of $10 \%$ in the import prices would make the wholesale, producer and consumer prices increase in $0.50 \%, 0.40 \%$, and $0.50 \%$, respectively. In turn, facing the same increase, the amount offered increases $0.02 \%$ and the demand decreases $-0.01 \%$. The joint effect of the import price on the trade balance is measured with the corresponding elasticity coefficient. In this case, the elasticity of the trade balance was quite elastic $(-17.23)$; however, due to the small average magnitude of the imports 
Un incremento de $10 \%$ en los precios de importación harán que los precios al mayoreo, al productor y al consumidor aumenten $0.50 \%, 0.40 \%$ y $0.50 \%$, respectivamente. Por su parte, ante el mismo incremento la cantidad ofrecida aumenta $0.02 \%$ y la demandada disminuye $-0.01 \%$. El efecto conjunto del precio de importación sobre el saldo de comercio se mide con el respectivo coeficiente de elasticidad. En este caso, la elasticidad del saldo de comercio resultó muy elástica (-17.23); sin embargo, debido a la pequeña magnitud promedio de las importaciones (2107 t), una disminución de $10 \%$ en el precio de importación origina un aumento en las importaciones de $1.72 \%(36.24 \mathrm{t}$ ) y un gasto de $\$ 633935.00$. De estos datos se concluye que el precio de importación tiene un efecto reducido sobre el mercado interno.

\section{ConClusiones}

La elasticidad precio de la oferta indica una relación directa e inelástica de la cantidad ofrecida respecto al precio real al productor de huevo. Es por esto que la continua caída del precio al productor de este alimento ha tenido un pequeño efecto en el descenso de la cantidad ofrecida. Por otro lado, la demandaprecio de huevo tiene una relación inversa e inelástica; debido a esto, la continua disminución del precio al consumidor de este producto ha hecho que la cantidad demandada aumente poco.

Las variables que determinan la oferta de huevo en México son los precios al productor de huevo, pollo, el alimento balanceado y la tecnología, mismas que resultaron inelásticas, siendo la tecnología la variable que más impulsa el crecimiento de la producción de huevo en México.

La demanda de huevo en México la determinan principalmente el ingreso y los precios reales al consumidor de huevo, de la carne de porcino, queso, chile y frijol, productos que resultaron complementarios en el consumo de este alimento.

La continua disminución del precio al consumidor y el aumento del ingreso son los factores que han impulsado en mayor medida el crecimiento de la demanda de huevo en México.

El incremento del precio al consumidor de huevo de $73 \%$, que se originó de julio a agosto de 2012 por efecto del brote de gripe aviar, debió ser de $45.78 \%$; el incremento adicional del precio en alta medida se debió a cuestiones especulativas.
$(2107 \mathrm{t})$, a decrease of $10 \%$ in the import price causes an increase in imports of $1.72 \%(36.24 \mathrm{t})$ and an expenditure of $\$ 633935.00$. From these data, it is concluded that the import price has a reduced effect on the internal market.

\section{Conclusions}

The price elasticity of the offer indicates a direct and inelastic relationship between the amount offered and the real producer price of egg. This is why the continuous fall in the producer price of this food has had a small effect on the decrease of the amount offered. On the other hand, the demand-price of egg has an inverse and inelastic relation; because of this, the continuous decrease in the consumer price of this product has caused for the amount demanded to increase slightly.

The variables that determine the egg offer in México are the producer prices of egg, chicken, balanced meal, and technology, which were inelastic, with technology being the variable that stimulates most the growth of egg production in México.

The egg demand in México is determined primarily by the income and the real consumer prices of egg, pork meat, cheese, chili and beans, products which were complementary to the consumption of this food.

The continuous decrease in the consumer price and the increase in income are the factors that have driven the growth in egg demand in México, to the greatest extent.

The increase in the consumer price of egg of $73 \%$, which was seen from July to August 2012 as a result of the impact of the avian flu outbreak, should have been $45.78 \%$; the additional increase to the price was due, to a great extent, to speculative issues.

- End of the English version -

\section{Literatura Citada}

BANXICO (Banco de México). 2013. http://www.banxico.org. $\mathrm{mx}$ (Consultado en febrero-mayo de 2013).

FAO (Organización de las Naciones Unidas para la Agricultura y la Alimentación). 2013. http://faostat.fao.org/ (Consultado en febrero-mayo de 2013). 
García Mata R., M. F. del Villar V., J. Alberto García S, J. Saturnino Mora F., y R. Carlos García S. 2004. Modelo econométrico para determinar los factores que afectan el mercado de la carne de porcino en México. In: Interciencia. Vol. 29, No. 8. Agosto.

García Mata R., M. Felix González M., R. Carlos García S., J. Saturnino Mora F., Adrián González E., y M. Angel Martinez D. 2013. El mercado del platano (Musa paradisiaca) en México, 1971-2017. In: Agrociencia. Vol. 47, No. 4.

Hu Frank B., Meir J. Stampfer, Eric B. Rimm, JoAnn E. Manson, Alberto Ascherio, Graham A. Colditz, Bernard A. Rosner, Donna Spiegelman, Frank E. Speizer, Frank M. Sacks; Charles H. Hennekens, and Walter C. Willett. 1999. A prospective study of egg consumption and risk of cardiovascular disease in men and women. In: The Journal of the American Medical Assocition. Vol. 281, No. 15. April.

INEGI (Instituto Nacional de Estadística, Geografía e Informática). 2013. http://www.inegi.org.mx. (Consultado en febrero-junio de 2013).

Jillon S. Vander Wal, Marth Jorene M., Pramod Khosla, K-L Catherine Jen, and Nikhil V. Dhurandhar. 2005. Short-Term Effect of Eggs on Satiety in Overweight and Obese Subjects. En: Journal of the American College of Nutrition. Vol. 24, No. 6. December.

López Lopez. E. 1990. Modelo econométrico del mercado del huevo en México 1960-1987. Tesis de maestría. México, ISEI-Economía, Colegio de Postgraduados-Montecillo.
Pérez Vera F. C., R. García M., M. Angel Martínez D., J. Saturnino Mora F., Humberto Vaquera H., y Adrián González E. 2010. Efecto de las importaciones de carne de porcino en el mercado mexicano, 1961-2007. In: Ciencias Pecuarias. Vol. 1, No. 2. Abril-Junio.

Rojas Rojas. M. M. 2005. Modelo econométrico del mercado del huevo en México, 1960-2003. Tesis de maestría. México, ISEI-Economía, Colegio de Postgraduados-Montecillo.

SAS. 2009. The SAS (Statistical Analysis System) System for Windows V 9.0. Sas Institute Inc. Cary, NC. USA.

SIACON (Sistema de Información Agropecuaria de Consulta SAGARPA). 2013. http://www.siap.gob.mx (Consultado en marzo de 2013).

SNIIM (Sistema Nacional de Información e Integración de Mercados SE). 2013. http://www.economia-sniim.gob.mx (Consultado en abril-mayo de 2013).

Scrafford C.G., N.L. Tran, L.M. Barraj, and P. J. Mink. 2011. Egg consumption and CHD and stroke mortality: a prospective study of US adults. In: Public Health Nutrition. Vol. 14 No. 2. February.

Stamer, Hans. 1969. Teoría del mercado agrario. España, Editorial Academia. $335 \mathrm{p}$.

Tomek G. William, y Harry M. Kaiser. 2014. Agricultural product prices. Ithaca and London. Cornell University Press. 394 p.

UNA (Unión Nacional de Avicultores). Compendio de indicadores económicos del sector avícola. México, 2011, 2012 y 2013. 